\title{
Horticultural Crops Research and Development in Ethiopia: Review on Current Status
}

\author{
Selamawit Ketema Ashinie ${ }^{1^{*}} \quad$ Tesfaye Tadesse Tefera ${ }^{2}$ \\ 1.Melkassa Agricultural Research Center, P.O. Box 436, Melkassa, Ethiopia \\ 2.Hawassa Agricultural Research Center, P.O. Box 06, Hawassa, Ethiopia
}

\begin{abstract}
Ethiopia is a country with great variety of climate and soil types that can grow diverse horticultural crops for home consumption and foreign markets. Currently, the majority of the horticultural crops product comes from the smallholder farms. However, their areas of production and their contribution to the country's total agricultural output were not well known. The development and expansion of horticulture sector is constrained with various production and research related problems and does not support efforts to transform the smallholder subsistence irrigated horticultural sector to a more market-oriented to contribute to the new Growth and transformation plan set by the country. The crops are very diverse and it has different constraints in every step along the value chain. Among several constraints, lack of high yielding and high quality cultivars for local market and export, appropriate management techniques, appropriate disease and insect pest control measures, quality seed supply, availability of inputs, lack of proper post-harvest technology, trained manpower and research facilities, lack of marketing and production infrastructure; and lack of seed production and distribution scheme are the major once. Despite the existing potentials the sector did not contribute as it supposed to be. This is mainly because of the limited resource allocation to research and development including the extension services. Therefore, diagnosis of problems and opportunities of the horticultural crops production in Ethiopia necessitates identifying, prioritizing and well document them at national level for possible recommendations, action research and intervention works. In addition, the existence of many actors and stakeholders in the horticulture value chain desires strong and dedicated institutional set up for successful development of horticulture in the country. Moreover, little or no actions are implemented in creating and strengthening linkages with local and international actors along the value chain of horticultural research and development. This paper summarizes the current horticultural crops research and development status; its achievements and challenges and suggests possible future actions that sustain the development of the sector in the country with special emphasis on fruit, vegetable and root and tuber crops.
\end{abstract}

Keywords: Horticulture, Root and Tuber, Vegetables, Fruits

DOI: $10.7176 / \mathrm{JBAH} / 9-13-01$

Publication date:July $31^{\text {st }} 2019$

\section{Introduction}

Ethiopia with diverse soil and climate comprising several agro-ecological regions provides ample opportunity to grow a variety of horticulture crops. Increasing the yield and production of horticultural crops is an important factor in ensuring Ethiopian food and nutrition security. Moreover, it will contribute to the economic growth and poverty reduction agenda of the country. Because of its strategic importance, the development strategy of Ethiopia puts emphasis on the intensification of crops production (Engida et al., 2011; MoFED, 2009; NPC, 2016). As stipulated in the Plan for Accelerated and Sustainable Development to End Poverty (PASDEP), GTP I and GTP II, horticulture was among the main agricultural products that received special focus and follow-up during the PASDEP, GTP I and GTP II plan period. Further special focus and attention is given for horticulture during the coming GTP II for more intensification of the crops and commercialization of smallholder.

Horticultural crops are rich in vitamins, carbohydrates and other nutrients that contribute to a major portion to an Ethiopian daily dish mix. Some nutritional deficiencies like vitamin A and C, and iron can be corrected by use of selected vegetable and root crops as well as fruits. In some areas of the country, root crops particularly potatoes and sweet potatoes are used as staple food for considerable portion of the population. Root crops in general and sweet potato in particular are drought resistant and serve as security food crops in drought prone areas. Furthermore, vegetables and root crops generate foreign currency earnings in the country. Horticultural crops play a significant role in developing country like Ethiopia, both in income and social spheres for improving income and nutrition status. In addition, it helps in maintaining ecological balance since horticultural crops species are so diverse. Further, it provides employment opportunities as their management being labor intensive, production of these commodities should be encouraged in labor abundant and capital scarce countries like Ethiopia (Bezabih et al., 2014). Though, the crops form insignificant part of total agricultural produce in the country. Because of the cereal based food and production habit of farmers, horticulture was a neglected sector. However, traditionally different fruits and vegetables, cabbages, enset, pepper, shallot has been produced by small farmers but recently exotic ones are also becoming important in commercial production. Even though horticultural crops production in Ethiopia has been small compared to other crops; currently fruit, vegetable and root and tuber crops are widely produced in all regions of 
the country with different intensities of about an area of 0.55 million ha with 60.78 tons of harvest (CSA, 2018). According to the nation rainy season data, from the total area covered vegetable, fruit and root and tuber crops have $49 \%, 33 \%$ and $19 \%$ share respectively. The irrigation potential of the country is estimated to be about 3.7 million hectares. Of the total potential, only about $20 \%$ to $23 \%$ of this potential is put under irrigated agriculture for both traditional and modern irrigation systems (Awulachew et al., 2007; MoA and ATA, 2011). The existing irrigation development in Ethiopia, as compared to the resources potential that the country has, is not significant and the irrigation sub-sector is not contributing its share accordingly. There has been also a steady increase in the demand for different horticultural crops production for local markets, export and processing sectors. Horticulture has been contributing immensely to the country's economic growth and development as the major export earning, however, the effort in the development horticultural commodities such as vegetables, fruits, root and tuber crops have been very much limited because of numerous production constraints (Asmare and Derbew, 2013; Bezabih and Hadera, 2007; Selamawit, 2013; Tesfaye et al., 2013).

Most of horticultural crops such as fruit, vegetable, root and tuber crops are perhaps among few crops that is cultivated by men and women but mostly harvested, processed and marketed by women. Hence, interventions on these crops are likely to impact the lives of women and children more than interventions on any other crops, thereby ameliorating gender disparity in access to resources. This paper summarizes the current horticultural crops research and development status; its achievements and challenges and suggests possible future actions that sustain the development of the sector in the country with special emphasis on fruit, vegetable and root and tuber crops.

\section{Major horticultural crops produced in Ethiopia}

Significant altitudinal variations exist in Ethiopia making the country suitable for the production of economic important vegetable crops. These includes (a) temperate zone ( $>2400$ m.a.s.l.) with average day temperatures of 0 $-16{ }^{0} \mathrm{C}$.; (b) sub-tropical zone $\left(1500-24000\right.$ m.a.s.l.) of $16-20{ }^{0} \mathrm{C}$; (c) tropical /arid zone $(<1500 \mathrm{~m}$.a.s.l.) of $27{ }^{0} \mathrm{C}$ or higher. There is a huge water resource for irrigation in the country that is favorable for sustainable production of high quality fruits and vegetable for the markets. It includes numerous rivers, lakes and streams like Abay and Awash River basins; Rift Valley lakes and reservoirs (Tana, Zwai, Koka Reservoir etc.).It is important to note that there are specific potential production belts in the different regions, favorable as pilot sites for commercial production of the fruits and vegetables industry that includes, the Tana Catchments, Upper Awash and lake region for different tropical fruits and vegetables Aaya Valley for tropical fruits and vegetables and Arba Minch for Banana, Chencha for high land fruits (Joosten et al., 2011). Fruit and vegetable cultivation is a new activity in many parts of the above mentioned belts and it has been given due attention very recently for its diverse economic benefits. The belts also differ in resources, technical capacity and practical implementation in the production of quality products for local market and export.

The bulk of root and tuber, fruit and vegetables are produced by small scale farmers and flowers are produced by commercial farms. The horticultural crops production in Ethiopia has been small compared to other crops but it has great potential since the climate is favorable for many horticulture products. According to the nation rainy season data (CSA, 2018), the total areas under fruits, vegetables and root crops estimated to be 0.55 million hectares with 60.78 million tons of harvest. About 17.66 million small-scale producers were engaged in production of these crops. Oromia and Southern National and Nationality People Regional (SNNP) state are the major producing regions with almost equal percent share (CSA, 2018).

The Central Statistics Authority (CSA) data is for rainy (Meher) season report, however most vegetables are produced under irrigation and give better yield. Besides the scattered small farmers, private investor cooperatives unions that are increasing in number also produce different fruits and vegetables for local and export markets. The overall productivity of the crops is lower in farmers' fields compared to the private investors' field (Selamawit, 2013). The private farms have better option to use better technologies and hence better productivity. Limited private companies are involved in the commercial production of fruits and vegetables like Strawberry, Fresh green beans, Cherry Tomato, Capsicum.

\subsection{Root and Tuber}

Root and tuber crops encompass the crops which are produced mainly for their edible modified edible roots. They include potato, sweet potato, yam, taro, cassava and enset. Root and tuber crops are regarded as the most common starchy staples that could provide a low cost energy in the daily diet of the society. In addition, these groups of crops are known for their appreciable amount of protein, essential vitamins, and minerals (Chandrasekara and Kumar, 2016). Most of the time root and tuber crops are classified as biennial and naturally prepared to be overwintered, whether in a store or outside (Sanginga, n.d.). Economically and socially important root and tuber crops are different in different region of the country. Some of the root and tuber crops like enset (Ensete ventricosum) and anchote (Coccinia abyssinica) are indigenous for Ethiopia or they are produced as food crop in Ethiopia only. Potato, sweet potato, enset, taro, yam and cassava are the major one that got research and development attention. Root and tuber crops covered about $1.63 \%$ of the area under all crops while cereals accounts 
71.69 (CSA, 2018). Nevertheless, Potatoes, sweet potatoes and taro added about $40 \%, 31 \%$ and $26 \%$ to the area of the root crop total. The same crops contributed $24 \%, 46 \%$ and $29 \%$ to the root crop production total in the same order (CSA, 2018).

\subsection{Vegetables}

The vegetable sub-sector is one of the important sub-sectors of the Ethiopian economy. High productivity and short growing period of vegetables, as compared to cereals and other annual crops, enables up to three production cycles per year thus making vegetables the most preferred crops for irrigated agriculture. Consequently, the return from vegetables per unit area is several folds higher than major cereals. The sub-sector also plays a great role in reducing unemployment as it is labour intensive and needs special skills and knowledge. According to the nation rainy season data, vegetables occupied about 0.27 million hectare in which $61 \%, 13 \%$ and $12 \%$ of the areas was under hot peppers (green and red), Ethiopian Kale and onion, respectively.

\subsection{Fruits}

The research and development in fruit sector in Ethiopia gives prior attentions for tropical and sub-tropical fruits. Despite their contribution especially in some high land part of Ethiopia temperate fruit such as apple and peach do not get attention. The CSA report also included only tropical fruits like banana, avocado, mango, citrus, papaya, pineapple and guava. In general, all fruits are cultivated on non-commercial production basis and yearly productions are from kitchen gardens. CSA, (2018) reports fruits cultivated by small holders who uses very low or no technological uses, except furrow irrigations during the dry season. Although data in terms of area coverage and production is not available, large area of fruits are cultivated by small scale, semi and commercial farms in the country and most of these growers use improved technologies. Fruit crops occupy about 104 thousand hectare of land in the country. Bananas contributed about $57 \%$ of the fruit crop area followed by avocadoes $(17 \%)$ and mangoes (15\%). The SNNP, Oromiya, Amhara, and Benishangul-gumuz regions are the four major producers of fruits (CSA, 2018).

\section{Research Achievements}

The research areas are selected based on the agricultural development policy of the country and on their immediate impact in the livelily hood of small scale farmers. It focused on high priority crops that are important income generation, source of nutrition and employment opportunities and that fits to year round production in different agro-ecological zones (AEZs) of the country and to fit for small and large scale production systems. The horticultural crops research currently is focused on generation of new technologies that addresses the urgent developmental needs of the sector. Due attention is given to the development of new varieties that are tolerant to disease, pest, salinity, moisture and heat stress and are adaptable to different agro-ecologies and socio- economic settings. Studies on insect pest management, irrigation and soil management, plant propagation techniques, marketing and postharvest technologies were carried out.

\subsection{Variety Development}

Since the establishment of Werer, Holleta and Nazareth agricultural research center, local collections of important fruits were made and improved fruits varieties were introduced from top producing countries, these materials were tested at multi-locations and verified. Some fruits varieties were released, some registered and others recommended during the last years (Asmare and Derbew, 2013; CSA, 2018; MoALR, 2017; Seifu, 2003). Currently a total of 44 varieties of improved fruits crops such as peach, bananas, avocado, mango, pineapple, papaya, grape, Ziziphus, figs etc were released, registered and recommended (Table 1). All these improved fruit crops varieties are available at all federal, regional and agricultural university research centers and in many private farms and nurseries in the country.

\subsection{Crop Management}

Various agronomic packages have been recommended to improve for performance of released varieties. Crop management experiments for fruit crops were conducted to generate best nursery and field management practices, to identify appropriate mulch type, mulching percentages and sucker management in pineapple, nutrient requirement (Daneil and Gobeze, 2012; Wondifraw et al., 2008), grape agronomy studies such as pruning and training, physiology studies such as dormancy and bud break were conducted (Tessema et al., 1994). Agronomic management of some temperate fruit (Endale and Kassa, 2008). Agronomic management of different fruit crops (Edossa et al., 2008).The results from these experiments are used in the fruit production systems in the country. Seed and dry bulb production practices of onion, shallot and for fresh market and processing tomatoes which included spacing, sowing date, rate of fertilizer (NP) application, irrigation frequency, planting method, transplanting and harvesting stages spacing for pepper have been investigated (Getachew et al., 2010; Lemma et al., 1994b, 1994a; Lemma, 2002; Lemma and Shimels, 2003; Selamawit, 2013). Planting date for cool season 
vegetable seed production also studied (Semagn and Fentahun, 2012).

The suboptimal agronomic techniques practiced by root and tuber growers in Ethiopia are undoubtedly one of the contributing factors to the existing low average yield. Agronomic studies have been undertaken by different research centers to develop a package of optimum management practices, together with improved cultivars, such as planting time, seed tuber size, population density, fertilizer rate, intercropping, harvesting time etc (Abebe et al., 2008; Gebremedhin and Taye, 2013; Tesfaye et al., 2013).

Table 1. Number of Fruit, vegetables and root and tuber crop varieties released/registered by research institute and private companies

\begin{tabular}{|c|c|c|c|}
\hline Crop & $\begin{array}{c}\text { No of varieties } \\
\text { released }\end{array}$ & $\begin{array}{l}\text { Year of } \\
\text { release }\end{array}$ & Remark \\
\hline \multicolumn{4}{|c|}{ Root and Tuber (76) } \\
\hline Cassava & 4 & $2005-2017$ & Released from research institute \\
\hline Enset & 6 & $2009-2017$ & Released from research institute \\
\hline Potato & 34 & $1987-2017$ & Released from research institute and by PLCs \\
\hline Sweet potato & 26 & $1997-2017$ & Released from research institute \\
\hline Taro & 3 & $2000-2017$ & Released from research institute \\
\hline Yam & 3 & $2010-2017$ & Released from research institute \\
\hline \multicolumn{4}{|l|}{ Vegetables (155) } \\
\hline Broccoli & 2 & $2011-2013$ & Introduced and registered by PLC \\
\hline Cabbages & 10 & 2011 & All are introduced and released by PLCs \\
\hline Carrot & 2 & $2014-2017$ & Released from research institute and by PLCs \\
\hline Cauliflower & 3 & $2013-2017$ & Introduced and registered by PLC \\
\hline Chinese cabbage & 1 & 2017 & Introduced and released by PLCs \\
\hline Fine bush bean & 4 & 2013 & Introduced and registered by PLC \\
\hline Garlic & 7 & $1999-2017$ & Released from research institute \\
\hline Lettuce & 12 & 2012 & Released from research institute and by PLCs \\
\hline Musk Melon & 1 & 2016 & Introduced and registered by PLC \\
\hline Okra & 2 & 2013 & Released from research institute and by PLCs \\
\hline Onion & 23 & $1997-2013$ & Released from research institute and by PLCs \\
\hline Pepper - chili & 6 & 2016 & Released from research institute \\
\hline Pepper-Hot & 17 & $2004-2017$ & Released from research institute and by PLCs \\
\hline Red beet & 1 & 2013 & Introduced and registered by PLC \\
\hline Shallot & 8 & $1997-2017$ & Released from research institute \\
\hline Snap bean & 2 & $2012-2017$ & Released from research institute \\
\hline Snow pea & 4 & $2013-2017$ & Introduced and registered by PLC \\
\hline Squash & 2 & $2013-2017$ & Introduced and registered by PLC \\
\hline Sweet corn & 1 & 2013 & Introduced and registered by PLC \\
\hline Tomato & 42 & $1997-2017$ & Released from research institute and by PLCs \\
\hline Watermelon & 5 & $2013-2017$ & All are introduced and released by PLCs \\
\hline \multicolumn{4}{|l|}{ Fruits (44) } \\
\hline Avocado & 6 & $2008-2017$ & Released from research institute \\
\hline Banana & 12 & $2006-2017$ & Released from research institute \\
\hline Date palm & 2 & 2017 & Released from research institute \\
\hline Fig & 2 & $2013-2017$ & Released from research institute \\
\hline Mango & 4 & $2007-2017$ & Released from research institute \\
\hline Papaya & 3 & $2015-2017$ & Released from research institute \\
\hline Pineapple & 2 & $2008-2017$ & Released from research institute \\
\hline Peach & 2 & $2015-2017$ & Released from research institute \\
\hline Wine grape & 9 & $2004-2017$ & Released from research institute \\
\hline Ziziphus & 2 & $2013-2017$ & Released from research institute \\
\hline
\end{tabular}

PLC: Privet limited companies

\subsection{Crop Protection}

Yield of horticultural crops is very low due to several biotic and abiotic factors among which disease and insects are major. In the last two decades, a wide range of research activities have been carried out at the EIAR and other research and higher learning institutions in order to find solutions to the problems. Technologies such as chemical, varietal, biological and physical methods of pest control have been developed and results reviewed and proceeding 
is published by Plant Protection Society of Ethiopia (PPSE) for the period 1985 - 2005 (Ferdu et al., 2009b; Gashawbeza et al., 2009; Mesfin et al., 2009; Mohammed et al., 2009).

Vegetable crops are generally more vulnerable to weed competition than cereal crops because many of them are short season crops and usually weak competitors to weeds. Common weeds of vegetable crops were identified and recorded. Parasitic weed (Orobanche spp) management practices like soil solarization, trap crops like beans and maize, flooding to suffocate Orobanche seeds, maintaining the nutrient requirement of the crop and removing the parasite before setting seeds have been found effective to reduce the Orobanche spp. in tomato field in the Rift Valley (Etagegnehu et al., 2009). Host plant resistance, botanical and trap cropping control for Orobanche on tomato; chemical weed control on onion, tomato and hot pepper were developed.

\subsection{Postharvest technologies}

Processing food crops help farmer to reduce spoilage and losses and to earn additional income due to value added product. Efficient postharvest technologies for different horticultural crops are lacking. There is a need to development of postharvest handling, storage, and value added products and processing system, product diversification, currently there are few plants involved in processing of grape, passion fruit and tomatoes. Processed products of fruit and vegetables like juices, peas, beans, carrot, cabbage and tomatoes are available in local supermarkets and groceries imported from different countries. There have been very limited research activities in processing like tomato paste, relish, sauce, in brine, juice, onion and leafy vegetable and banana dehydration, etc to substitute import products. However, the promotion was not given due attention. Therefore, outreach activities did not address as many possible as the needy partners.

In order to extend the shelf-life of onion dry bulbs, storage structures were developed from corrugated iron sheet and thatched roof. It was possible to reduce weight loss to around $10 \%$ and the product can stay up to 1.5 month. This enables sustainable supply and also keeps both sellers and buyers from unexpected prices changes (up and down). Under similar storage the seed bulbs can be stored for more than two months with below $15 \%$ weight loss (Endeshaw et al., 2008). Pre harvest ComCat ${ }^{\circledR}$ treatment, modified atmospheric package, storage in evaporative cooling, as well as disinfecting with chlorinated water, decreased postharvest decay of tomato and insure a relatively longer shelf life and better quality (Melkamu et al., 2008).

Many postharvest and mechanization experiments were conducted; among solar drying of banana slices using Modified Local Kawanda Solar Cabinet Drier was conducted at Jimma (JUCAVM) (Mulatu et al., 2012). An experiment was conducted to evaluate the effect of bunch bagging and male-bud removal on various yields, quality characteristics and maturity time of banana at Ziway (Abiyot et al., 2012). Experiment was conducted to see the response of pineapple fruit to inorganic and inorganic fertilizers at Dale and Aleta Chuko districts in Sidama Zone of SNNP (Daneil and Gobeze, 2012). Utilization and quality evaluation of banana, papaya, and grapes vine varieties (Senayit et al., 1994). Experiment was conducted to evaluate the performance of cooling chambers to extend the shelf life of mango and sweet orange (Debele and Fekadu, 2008).

\section{Problems of horticultural crop production and research}

Despite the importance of horticultural crops in the country economy, contribution to food self-sufficiency, food security, dietary and medicinal value, and other benefits, its production, utilization and marketing are commonly various constraints. The most important problems of horticultural crops that the producers and traders facing are lack of sufficient improved varieties, lack of quality planting materials and supply system, lack of appropriate production technology, biotic factors mainly disease and insect pests, abiotic factors majorly drought, lack of improved harvesting, post-harvest handling and storage facilities; Rain fed system of production and most of the production is from the small scale farm; Cereal based research, extension and consumption system and insufficient socio-environmental protection of large scale horticultural farms.

\subsection{Insufficient number of improved varieties of horticultural crops}

Horticultural crops produced in the country are clustered in to root and tuber, vegetables and fruits, beverages and flowers. Some of the horticultural crops such as enset and anchote are indigenous for Ethiopia or they are produced as food crop in Ethiopia only. They have got little focus in research and has very few number of varieties were released for official production. More over some of the crops verities were released before ten years which might be out of the production or even not popularized to the producers.

In Ethiopia there are a number of research centers and higher learning institutes engaged in agricultural technology development and adaptation activities. But most of them focuses on cereal crops improvement and agronomic researches. That is one of the most important reasons to limited number of varieties of horticultural crops. Some of officially released varieties are out of production due to breaking of diseases and unwillingness of the farmers to produce them because of the natural behavior of the varieties not being under the interest of the farmers. Crops like cabbage and carrot were produced and consumed for long time but less focus is given to these crops. There seed are introduced from the abroad and their seed supply, productivity, genetic quality, disease and 
pest reaction under farmers' level is not known. Some of horticultural crops varieties are introduced from abroad and registered in our variety registry annual book.

\subsection{Lack of quality plating materials/seeds}

The most bottleneck of horticultural crops development of the country is lack of improved seed in required quality and quantity. This is because of there was and is no governmental or non-governmental organization responsible for the multiplication and distribution of horticultural crops seeds (Lemma et al., 2012). Except research centers, some innovative farmers, very few universities, there is no any formal and accountable seed/planting materials producer in the country. The only formal state owned crop seed producer in the country is Ethiopian seed enterprise which covers only $10 \%$ of the seed demand of the producers. The larger proportion of the products of the enterprise are maize and wheat seeds and it plays a role in more accessible areas (Bishaw et al., 2008). Consequently, farmers engaged in horticultural crops obtain either from their own saving, relatives, neighbors, local market, small shops and others which are supposed to be low in yield potential and prone to most of the diseases and insects.

Despite the possible of seed production in Ethiopia, the vegetable production sector relies mainly on imported seeds except for very limited hot pepper and kale traditional production. The imported seeds have negative impact on farmers' welfare and the demand for foreign currency (Dawit and Hailemariam, 2008).

\subsection{Seasonality of production}

Since most vegetables are grown under rain fed conditions the supply fluctuates seasonally. The season of lowest vegetable supply is the main rainy season between June to mid-September when also prices are the highest. Between October and January there are moderate supply of fresh vegetables but starts to rise in February and reaches its peak level in April and May (Tadesse, 2015). There is a highlight of production of horticultural crops especially onion and tomatoes are carried out by using irrigation in some parts of the country like lake tana shore of Amhara region and central rift valley areas of Oromia region where at least two cycles of irrigations are being practiced (Fantahun and Yigzaw, 2011). But most of our farmers are dependent on rain fed system of production, and rainfall pattern is more or less erratic which has direct impact on the quality and quantity of the produce. The potential for irrigation in Ethiopia is estimated to be about two million hectares. Due to limited experience in water management and control, limited capital available for investment and the diverse climate and disease vectors characteristics of the lowland areas (where most irrigation potential is located), irrigated agriculture is far below its potential. Thus production is heavily dependent on rainfall and uses little capital and technology. Consequently, the average productivity of both land and labor is extremely low and variable from season to season. Despite these favorable resource donations, agricultural production has remained mostly close to subsistence level (Tadesse, 2015).

\subsection{Biotic factors mainly disease and insect pests}

Horticultural crops produced in the country experience the most common world diseases and insect pests, for instance Solanaceous family suffers from late blight (Phythopthra infestance), bacterial wilt, early blight etc. Particularly, potato is damaged by potato tuber moth whereas sweet potatoes mainly attacked by sweet potato weevil, sweet potato butter fly and beetle. It also gets attacked by blights, soft rot and virus diseases.

Horticultural crops are being suffering from a number of diseases caused by virus, fungus, bacteria, nematodes etc. Bacterial Canker, Speck and Spot, Bacterial Wilt, Fusarium Wilt, Early Blight, Late Blight, Powdery Mildew, Root-knot Nematodes, Viral Diseases(Tomato Yellow Leaf Curl Virus), Blossom-end Rot are some of diseases that attach tomato at different stages of growth (Mesfin et al., 2009; Mohammed et al., 2009; Wondirad et al., 2009). Different species of insect pests attack horticultural crops in Ethiopia and cause considerable damage and yield losses. Most of the insect pests are common for majority of the crops while some are specific to a given crop (Ferdu et al., 2009b, 2009a; Gashawbeza et al., 2009)

\subsection{Research}

Ethiopia used to grow horticultural crops under uncontrolled growing system i.e. in the natural field condition using classical means of propagation or multiplication, seed production and breeding activities. No/little tissue culture or biotechnology activities were so far undertaken in the country which is highly decisive for in vitro propagation and ex-situ conservation of germplasms. More over horticultural crops are suffering from bacterial, fungal and viral diseases that could easily be cleaned by using tissue culture and/or biotechnology laboratories. With some exceptions, understanding the importance of these new technologies for micro propagation and virus disease clean up, the infrastructure facilities are under construction in few selected research centers.

Due to the biological nature of horticultural crops such as susceptibility to disease, principality, delicacy for handling and the like, no anyone is interested to work research activities/experiments on them. Rather every researcher is inclined to conduct research works on field crops which are very easy to hand and early to see the research. The researchers and higher learning institutes which are engaged on the technology development of 
horticultural crops has no any special treatment. The case in point is the researchers' promotional policy of the country treats all researchers in equal bases. Donor and externally funded projects have also inclined to support research activities focusing on grain improvement of cereal crops though the importance and higher contribution of horticultural crops in food security and attaining food self-sufficiency. More over annual budget appropriation for horticultural crop research in the country is very small in comparison with other crops.

\subsection{Postharvest handling}

In agriculture, postharvest handling is the stage of crop production immediately following harvest, including cooling, cleaning, sorting and packing. The instant a crop is removed from the ground, or separated from its parent plant, it begins to deteriorate. Postharvest treatment largely determines final quality, whether a crop is sold for fresh consumption, or used as an ingredient in a processed food product.

The purpose of packing, transport and storage is to mitigate the postharvest loss gap between producer and consumer, and/or reduce the time interval between harvesting and consumption. The loss of vegetables between production and consumption is estimated to be $25-35 \%$. As the farmers have no storage facilities at their disposal and the products they harvest are usually exposed to the influence of the weather until they are collected by the end users and the trade also does not operate any intermediate storage system for carrying ever supply to obtain better prices. In general several types of transportation means are used to market horticultural crops. These include the human labor, donkeys, mules, some public transport, rented pickups, mini trucks and large trucks. At the farm level, limited availability of the means of transport causes serious problems to the small scale producers. Packaging, which is extremely important in the marketing of fruit and vegetables, is rudimentary in Ethiopia. The shortage of containers causes serious problems especially for the peasants and often their crops are loaded on to the transport vehicles loss their quality and weight. The type of containers used by the general trade includes baskets with no uniform size for kale, lettuce, carrots, and jute sacks for marketing onions, shallots, potatoes but also for cucumbers, melons and cabbages. These containers have no temperature and moisture regulating mechanisms to avoid/minimize postharvest/transport losses. Post-harvest losses in percent due to bruising, over ripening, water losses, over chilling and decay of root vegetables, immature fruit vegetables, mature fruit vegetables and fruits, and flower vegetables are 15, unknown, 25, 50 and 10, respectively (MOA and ATA, 2013).

Data from South Wollo, Ethiopia indicated that the major causes of postharvest losses were preharvest and post-harvest disease and insect pest infection. The general postharvest losses of horticultural commodities was estimated as $<5 \%$ to $20 \%$. The losses of individual crops at different stages of handling (farmers level, transportation and storage) such as banana $(1.5 \%, 1.2 \%$ and $4.5 \%)$, orange $(3.04 \%, 1.2 \%$ and $3.6 \%)$, mango $(1.6 \%, 1 \%$ and $3.7 \%)$, papaya $(1.5 \%, 1 \%$ and $3.3 \%)$, tomato $(2.5 \%, 2.5 \%$ and $5.9 \%)$, onion $(3.3 \%, 1.1 \%$ and $3.7 \%)$, cabbage $(4.3 \%, 2.8 \%$ and $4.2 \%)$ and carrot $(2.8 \%, 1.2 \%$ and $3.8 \%)$ respectively. In a similar study, losses in tomatoes ranged from 18 to $22 \%$ while losses in onion, potato, and yam ranged from 9 to $12.4 \%$. Post-harvest losses in the study area are highly associated with the type of means of transportation (horseback, mule, donkey, human labor, small pickups), packaging materials (sacks with no aeration), the type of the road and distance to local market (Seid et al., 2013). Other study conducted at Kombolcha Zone of Oromia regional indicated that existence of high postharvest losses due to improper harvesting, handling, packaging and poor facilities to market. The result of the sample farmers' survey shows that $34 \%, 25.4 \%$ and $20.2 \%$ of tomato, potato and cabbage damaged before it reach to market (Abraham, 2013).

Table 3. Storage temperature, storage life and estimated postharvest losses of vegetable crops in Ethiopia

\begin{tabular}{|l|l|l|l|}
\hline Vegetable & $\begin{array}{l}\text { Storage } \\
\text { temperature }\left({ }^{\circ} \mathrm{C}\right)\end{array}$ & Storage life (wks) & $\begin{array}{l}\text { Est. post- harvest loss } \\
(\%)\end{array}$ \\
\hline Tomato & $13-15$ & $0.5-1.0$ & $40-50$ \\
\hline Potato & $10-16$ & $1.5-2$ & $10-20$ \\
\hline Onion & $7-13$ & $20-30$ & $10-20$ \\
\hline Sweet pepper & $7-13$ & $2-3$ & $15-25$ \\
\hline Green beans & $4-7$ & $1.0-1.5$ & $20-25$ \\
\hline Garlic & $15-18$ & $20-30$ & $10-25$ \\
\hline
\end{tabular}

Source: (MOA and ATA, 2013)

\subsection{Abiotic factors majorly recurrent drought}

In today's climate change scenarios, crops are exposed more frequently to episodes of abiotic stresses such as drought, salinity, elevated temperature, flooding and nutrient deficiencies. These stresses limit crop production. Abiotic stress can persistently limit choice of crops and agricultural production over large areas and extreme events can lead to total crop failures. Abiotic stresses adversely affect the livelihoods of individual farmers and their families as well as national economies and food security. Drought in Ethiopia occurs during the different seasons that occur in different regions in the country and it exists when seasonal rainfall drops below normal by almost $30 \%$ to $50 \%$ (Getachew, 2018). Water shortage may lead to the reduction of maturity period, crop growth rate, 
harvest index and finally yield. Abiotic stresses such as drought, excess salt, extremes of temperatures (low or high) and mineral nutrient deficiencies impose severe production constrains on food, fodder, fiber and fuel production. Ethiopian agriculture is mostly rain fed, whereas inter-annual and seasonal rainfall variability is high and droughts are frequent in many parts of the country. Rainfall variability has historically been a major cause of food insecurity and famines in the country (Woldeamlak, 2009). Although some of horticultural crops like cassava, sweet potato, are moderately/less sensitive to drought, most of them are highly affected by prolonged low moisture stress. In Ethiopia since 2007 onwards the area of production decreased because of scarcity of irrigation water associated with extended drought for some growers (Ambecha et al., 2012). Fruit yields experienced a sharp decrease in the late 1990's and late 2000's. These sharp drops are more likely associated to severe drought conditions. Increase in drought conditions led a shift from the production of cash crops such as fruits to the production of food crops. As the incident of drought worsen, cash crops production in Ethiopia could further decrease because of weather stress and agricultural neglect (Nicolas et al., 2012).

\section{Opportunities}

Ethiopia has got an immense potential to develop intensive horticulture on small scale as well as on commercial scale. Some of the favorable factors that contribute to an overall investment are:

1. Proximity to lucrative markets: Ethiopia is strategically located in a very feasible position in the world map which is relatively in the near distance to the Middle East, East and central Africa, European countries and the others.

2. Agro-climatic suitability and rich water resources for diversified irrigated agriculture: With a favorable climate, abundant labor, land and water resources, most regions of the country are suitable for the production of a wide range of tropical and sub - tropical fruits, vegetables and flowers.

3. Growth/rise of demand for horticultural crops, particularly in urban areas,

4. The high productivity of horticultural crops as compared to cereals,

5. Export possibilities of these crops are very encouraging

6. Favorable policy support by the government, and frequent effort of research centers, higher learning institutes and private sectors to develop and disseminate new improved technologies of horticultural crops

7. Cereal crops price increment from time to time that let people shift the consumption behavior from cereal products to horticultural crops products. This also lead consumers to mix or supplement the cereal crops with the horticultural crops products.

8. Presence of development partners (NGOs. Projects, Donors, etc) can be considered as an excellent resource for dissemination of technologies.

9. High demand of farmers for clean, high yielding, disease and insect resistant varieties and sufficient seed/planting materials.

10. Farmer's knowledge improvement in horticultural crop production, utilization of technologies and small scale irrigation facilities by using harvested rain water, lake water or water from ponds and streams.

\section{Seed/planting material supply and distribution}

The informal seed system is the major source of vegetables for varieties for which released varieties do not exist. The supply of vegetable seeds depends on informal system of farmer-saved seeds particularly for kale, Ethiopian mustard, pumpkin, hot pepper as well as seed potato and sweet potato cuttings for planting. Community-based seed production (also called the intermediate seed system with some regulatory oversight) largely serves seed supply for potato, onion, sweet potato, and to a limited extent tomato. The community-based vegetable seed production (e.g. for onion and potato) involves model farmers, farmers cooperatives, individual seed producers with spirit of entrepreneurship and supported by research centers, bureaus of agriculture, NOGs and seed projects(Bezabih et al., 2014) .

The bulk of vegetable seeds (onion, carrot, beetroot, tomato, Swiss chard, lettuce, cauliflower and leek) are exported by private seed importers and parastatal enterprises such as EtFruit and AISCO. The seed import is predominately made from Europe counties like the Netherlands, Italy, Germany and France. Available data shows the quantity of imported vegetables is increasing, primarily because of increasing vegetable production both under rain fed and irrigation. The imported seeds are distributed by local traders, farmers' cooperative/union, bureaus of agriculture, and NGOS. Such seeds are rarely checked for quarantine and quality by the seed regulatory department of the Ministry of Agriculture and the regional bureaus of agriculture (Bezabih et al., 2014).

\section{Supporting Service and Infrastructure}

For horticultural crops in order to produce throughout the year irrigation is important. In recent years, the government of Ethiopia has demonstrated commitment to irrigation, emphasizing its importance to the country in its Growth and Transformation plan (GTP). Through the Ministry of Agriculture (MoA) and the Ministry of Water and Energy (MoWIE), the government is pursuing irrigation projects at all levels of scale (MoA and ATA, 2011; 
MoA, 2011). Given the importance of crop rotation in sustaining soil quality, and the high price of horticultural crops outside the rain-fed season, farmers usually up to grow fruits and vegetables on irrigated plots. Horticultural crops have the largest potential return on investment to farmers at current prices, given the agronomic irrigation potential in those areas (MoA and ATA, 2011).

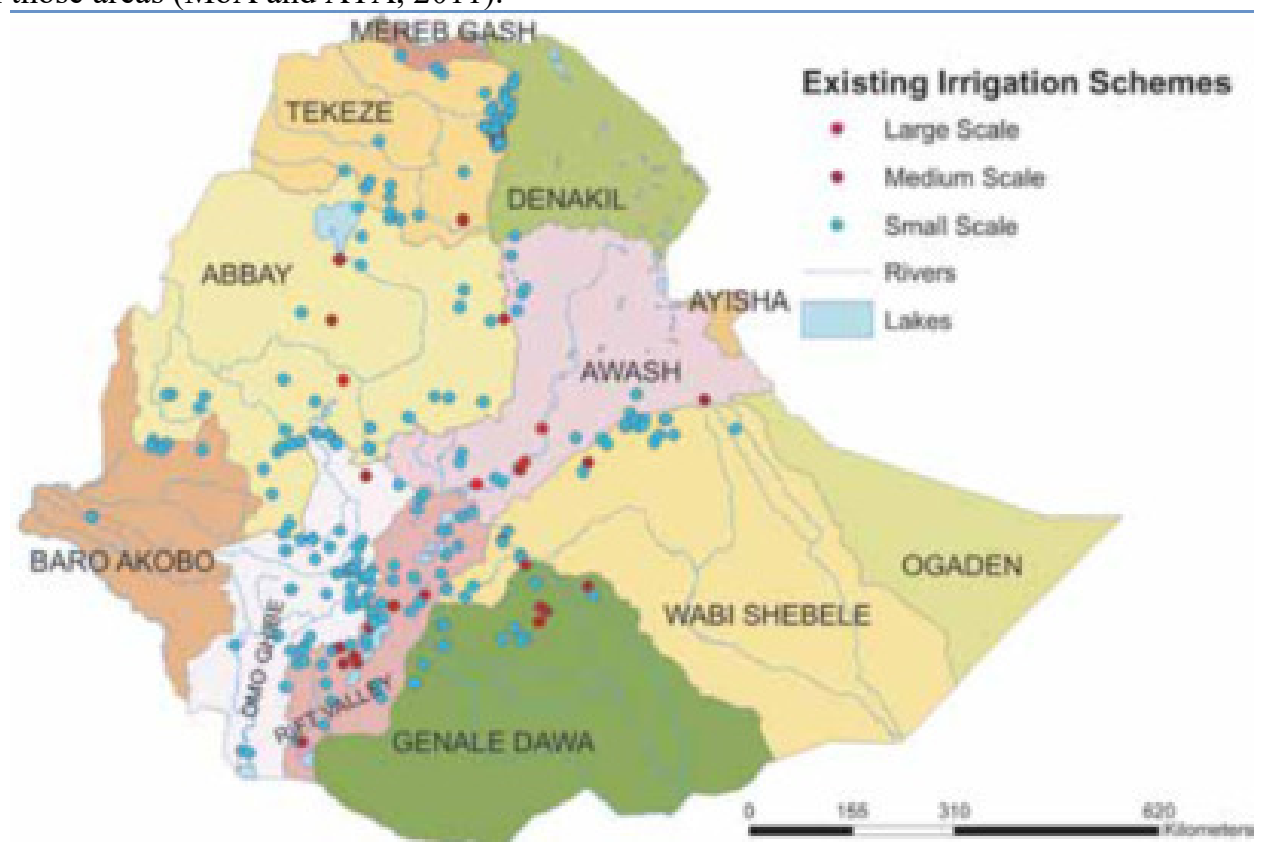

Figure 2:Existing irrigation schemes distributed in the regional states of Ethiopia (Awulachew et al., 2007)

Irrigation is essential for modern export oriented horticultural production. In many parts of the country the irrigation possibilities are potentially good, but existing infrastructure is not yet developed on a large scale. Modern irrigation facilities with drip irrigation and/or efficient sprinkler systems are scarce. Canal systems for flood irrigation are the norm in the main horticultural production regions. Water utilization efficiency is often low and in some areas undermines the sustainability of the horticultural systems.

Commercial supply services for production equipment, agro-chemicals, etc. for modern horticultural systems have developed over the past few years for the floriculture sector. Virtually all production equipment and inputs are imported from Europe, Israel, India and China. Specific agrochemicals, seeds and other supplies for the modern fruit and vegetable cultivation, however, are not always available. Most commercial horticultural growers therefore import their own inputs. Supply and maintenance services for irrigation equipment, greenhouses, cooling, etc. are available in Ethiopia. The supplies of improved seeds, planting material and other inputs for the smallholder vegetable and fruit growers are poorly developed. Extension support services for the smallholders are of a poor quality and market information services are not available.

Table 1. Existing and potential irrigated areas in Ethiopia

\begin{tabular}{lcccc}
\hline \multicolumn{1}{c}{ Region } & Irrigable Potential (ha) & \multicolumn{3}{c}{ Existing irrigation facility (ha) } \\
\cline { 3 - 5 } & & Traditional & Modern Small & Modern medium and large \\
\hline Oromya & $1,350,500$ & 56,807 & 17,690 & 31,981 \\
Amahara & 500,000 & 64,035 & 5,752 & - \\
SNNPR & 700,000 & 2,000 & 11,577 & 6,076 \\
Tigray & 300,000 & 2,607 & 10,000 & - \\
National Total & $\mathbf{4 , 2 5 6 , 4 5 7}$ & $\mathbf{1 3 8 , 3 3 9}$ & $\mathbf{4 8 , 0 7 4}$ & $\mathbf{6 1 , 0 5 7}$ \\
\hline
\end{tabular}

Source: (Joosten et al., 2011) 
Table 2. Irrigation Potential in the River Basins of Ethiopia

\begin{tabular}{lccccc}
\hline Basin & Catchment Area (km2) & \multicolumn{4}{c}{$\begin{array}{c}\text { Irrigation potentials (Ha) } \\
\text { (Respective recent master plan studies) }\end{array}$} \\
\cline { 3 - 5 } & & Small Scale & Medium Scale & Large Scale & Total \\
\hline Abbay & $198,890.7$ & 45,856 & 130,395 & 639,330 & 815,581 \\
Tekeze & $83,475.94$ & $\mathrm{~N} / \mathrm{A}$ & $\mathrm{N} / \mathrm{A}$ & 83,368 & 83,368 \\
Baro-Akobo & $76,203.12$ & $\mathrm{~N} / \mathrm{A}$ & $\mathrm{N} / \mathrm{A}$ & $1,019,523$ & $1,019,523$ \\
Omo-Ghibe & 29,000 & $\mathrm{~N} / \mathrm{A}$ & 10,028 & 57,900 & 67,928 \\
Rift Valley & 52,739 & $\mathrm{~N} / \mathrm{A}$ & 4,000 & 45,700 & 139,300 \\
Awash & $110,439.3$ & 30,556 & 24,500 & 79,065 & 134,121 \\
Genale Dawa & 172,133 & 1,805 & 28,415 & $1,044,500$ & $1,074,720$ \\
Wabi Shebele & $202,219.5$ & 10,755 & 55,950 & 171,200 & 237,905 \\
Denakil & $63,852.97$ & 2,309 & 45,656 & 110,811 & 158,776 \\
Ogaden & 77,121 & & & & \\
Ayisha & 2,000 & & & &
\end{tabular}

Source: (Awulachew et al., 2007)

\section{Horticultural crops Market}

Most of the fruits, vegetable and root and tuber crops produced by small scale farmers are consumed locally, but little export to middle east and regional market like Djebute, Somali and Sudan.

\subsection{Export Market}

Ethiopia has a huge potential for the production and export of horticulture farming that can be competitive in the global market with additional proximity of its geography which is located in the gateway of Africa, Middle East, and Europe. The sector is the fourth largest contributor of export income for the country in US\$ 307.04 million in the year $2017 / 18$. Floriculture contributes much of the share in around $79 \%$ while the expanding vegetable, fruits, and herbs have $21 \%$ share of the revenue (https://ehpea.org/sectoral-information/).

Horticultural cops specially fruit and vegetable have been exported to neighboring African countries (Sudan, Somalia, Djibouti), the Middle East and the EU and generated the much needed foreign currency.

The EU market is one of world's largest markets for fresh horticultural floriculture product. Sub-Saharan African (SSA) countries are key exporting partners to this market. Entering the EU market with one or several niche products and a minimum of logistical infrastructure was fairly easy until some years ago. However, due to various developments, such as the harmonization of the EU, the introduction of the Euro, and the growing market share of international retail chains, the EU market is now increasingly showing specific "European characteristics" (World Bank, 2005).The interaction between a pan-European market and a number of other regional markets makes it an attractive but also complex market. With regards to horticultural products, supplying the EU market now requires "a license to deliver" based on professionalism in production, logistics and risk management(World Bank, 2005). The food safety issue is gaining importance. This means the exports of SSA countries to EU market may increase substantially if they manage to fully guarantee and demonstrate food safety(World Bank, 2005).

The horticultural crops types exported to the European market from Ethiopia vary but green "bobby" beans are predominant. The supply is limited to a relatively short export season from December through April or May when Europeans do not produce fresh beans due to the winter season (Joosten et al., 2011). The fresh onions, tomatoes, cabbage and potatoes that are mainly produced by small scale farmers are exported to Djibouti and from there to Saudi Arabia, Yemen and other Middle East countries. The produce is exported in bulk without any value addition and tends to have a relatively low value. Due to poor handling and lack of proper facilities during transportation produce often arrives in poor condition at destination.

Processed fruit as juice concentrate or pulp appear to have good market potential as well. The great advantage of juice concentrates and fruit pulp compared to fresh fruits and vegetables is the fact that the products are far less perishable. However, adherence to high quality and food safety standards are also in this sub-sector a precondition. Pulps and juices have high provenance value for health and/or corporate social responsibility (CSR) initiatives, which is attractive for EU retailers. Africa Juice recently started with amongst others passion fruit and mango cultivation at UAAIE and is about to start exports of processed fruit ingredients and concentrates towards European customers. Other European customers have shown interest for both mainstream conventional volumes but also for niche market propositions like fair-trade and/or organic ingredients (Joosten et al., 2011).

Compared to some of its neighboring countries Ethiopia is better endowed with soils, climate and irrigation opportunities. Ethiopia could become the main supplier of vegetables and fruits to its neighbors (Sudan, Djibouti, Somalia) for fresh fruits and vegetables (Joosten et al., 2011). Regional markets show growth perspective. Demands for fresh produce in the neighboring countries (Djibouti, Sudan and Somalia) are high, but efficient 
supplies of quality products are generally hampered by lack of market transparency and monopolistic control of the market by a limited number of exporters and/or importers. Under the current conditions it is not viable for producers, farmer groups, traders and logistic service providers to make the necessary investments in production improvements and better post-harvest handling of the fruits and vegetables.

With improved market transparency and a level playing field in the export markets, the necessary improvements in cultivation, postharvest handling and logistics can be addressed. Choice of planting material, soil fertility management, enhancing irrigation efficiency and better plant health management are all factors that can contribute to improved productivity in the horticultural sector. Lack of sorting, grading, packing and conditioning are additional factors that reduce the exports of fresh produce in the supply chains aimed at the regional export markets. According to Ethiopian Horticulture Producer Exporters Association (EHPEA), Ethiopia has gained 300 million USD from flower and other horticulture products in 2017. From this, flower export takes the highest share.

\subsection{Local Market}

Horticulture is a market-oriented sub-sector, increasingly controlled by large nationally operating retail chains. In Ethiopia FVRT crops are seasonal in supply. Most farmers in a given agro-climatic belt produce similar crops and varieties during the same period that lead to surplus supply to the market. Thus, farmers face high marketing risks, which affect their income and are discouraged in the production of such perishable crops even if it generates high income. According to Dawit and Hailemariam (2008)) the major vegetables marketing channels in the Rift Valley belt are direct from farmers to wholesalers ( $96 \%$ of the total. produce) and $4 \%$ to small retail trader. The major volume of production is during the rain and causes chaotic chop in price. During the dry season (April and May) the demand is high because of the long fasting period. The prices are also higher during the dry season compared to the rainy period. In urban and pre-urban areas ETFRUIT, small shops and road side markets are major suppliers to consumers. Speculators and brokers determine the price with little or no bargaining power of farmers. The major problems are lack of infrastructure for storage during the glut period, poor market access, poor access to transportation and vigor competition among producers.

\section{Conclusion and Recommendation}

Ethiopia has huge potential for horticulture production and marketing mainly due to abundant water sources, fertile land, labor force, conducive Government policy and its geographic location for the export market to the various destinations. Despite the existing potentials the sector did not contribute as it supposed to be. This is because of the limited resource allocation to research and development including the extension services.

Fruits and vegetables are important supplementary source of food and nutrition. To meet the increased needs of local and export markets, low productivity and high rate of post-harvest losses due to poor handling remains to be major problems. Diseases and pests are major contributors to the loss. Increased technologies development and improved distribution system are necessary to attain the ever increasing demand of fruit and vegetable in the local and export markets. The following areas need to be addressed to meet the increase needs of fruits and vegetable for local and export market.

- Strengthening the technology generation and transfer through participatory approach of stake holders, scaling up of accepted technologies

- Investigate the genetic potential of locally available fruit and vegetables for wider application

- Support for credit and appropriate price incentives for farmers to compete in the emerging market.

- Private companies and farmers union should be encouraged to involve in the seed and planting materials production business

- $\quad$ Strengthen value addition

- Strong promotion and demonstration programs be launched with collaboration of different stakeholders

- Sensitize consumers on the need of healthy and high quality produces

- Development and promote different technologies that satisfy safety standards for local and export markets and promote protected cultivation in small scale farmers

- Regulate the market supply of horticulture products to secure sustainable income by adapting the production system to the market demands and opportunities.

- Build and strengthen the capacity of key stakeholders in horticulture production to improve production and productivity.

- Improve the production technology and irrigation facilities to promote modern irrigation and increase productivity.

- Improve the input supply system for the farmers and provide them with the right inputs in sufficient quantity and on time.

- Encourage the farmers to diversify their crop varieties and their export earning options, and improve the 
quality of the products they supply to export markets.

- Establish and enforce a legal system in the marketing management and define quality parameters, standards and grades by establishing regulatory frameworks to enforce pricing based on standard.

- Improve the market information delivery system

Since vegetable research is an emerging sector, stronger collaboration with concerned regional and international institutions in experience and material exchange is essential

\section{Reference}

Abebe, T., Yigzaw, D., Ermiase, A., 2008. Review of Potato and Sweet Potao Variety Development and Agronomic Research Achievement in Northwest Ethiopia, in: Proceedings of the First Conference of Ethiopian Horticulture Science Society 23-24 March 2006,. Addis Ababa, Ethiopia, pp. 139-148.

Abiyot, A., Seifu, G.M., Bezuayehu, T., 2012. Effect of Bud Removal and Bagging of the Bunch Maturity Time, Yield, and Quality of Banana (Musa Sp.) in the Central Rift Valley of Ethiopia, in: Eshet, D., Asfaw, Z., Lemma, D., Zemedu, W., Hailemichael, K., Getachew, T., Yehenew, G. (Eds.), Proceeding of the 3rd Biennial Conference of Ethiopian Horticultural Science Society. 4-5 February 2011. Addis Ababa, Ethiopia, pp. 176-200.

Abraham, T., 2013. Value Chain Analysis of Vegetables: The Case of Habro and Kombolcha Woredas in Oromia Region, Ethiopia. Haramaya University, Ethiopia.

Ambecha, O.G., Struik, P.C., Emana, B., 2012. Tomato production in Ethiopia: constraints and opportunities. "Resilience of agricultural systems against crises."

Asmare, D., Derbew, B., 2013. Production, Research and Development Status of Fruits in Ethiopia, in: Brhane, G., Seme, D., Solomon, B., Taye, B., Solomon, H., Gete, and Z. (Eds.), The State of Agricultural Science and Technology in Ethiopia. Held at International Livestock Research Institute (ILRI) Addis Ababa, Ethiopia. 28-30 November 2011. Ethiopian Academy of Sciences (EAS), Addis Ababa, Ethiopia, pp. 97-135.

Awulachew, S.B., Yilma, A.D., Loulseged, M., Loiskandl, W., Ayana, M., Alamirew, T., 2007. Water Resources and Irrigation Development in Ethiopia. Colombo, Sri Lanka: International Water Management Institute. 78p. (Working Paper 123).

Bezabih, E., Amsalu, A., Tesfaye, B., Temesgen Milkessa, 2014. SCOPING STUDY ON VEGETABLES SEED SYSTEMS AND POLICY IN ETHIOPIA. AVRDC: The World Vegetable Center. Addis Ababa, Ethiopia.

Bezabih, E., Hadera, G., 2007. Constraints and Opportunities of Horticulture Production and Marketing in Eastern Ethiopia. Drylands Coordination Group (DCG) Report No. 46.

Bishaw, Z., Sahlu, Y., Simane, B., 2008. The status of the Ethiopian seed industry, in: Marja H. Thijssen, Zewude Bishaw, A.B. and W.S. de B. (Ed.), Farmers, Seeds and Varieties: Supporting Informal Seed Supply in Ethiopia. Wageningen, Wageningen International, p. 348.

Chandrasekara, A., Kumar, T.J., 2016. Roots and Tuber Crops as Functional Foods : A Review on Phytochemical Constituents and Their Potential Health Benefits. Int. J. Food Sci. 1-15. doi:10.1155/2016/3631647

CSA, (Central Statistics Agency), 2018. The Federal Democratic Republic of Ethiopia. Agricultural Sample Survey. Report on Area and Production of Major Crops for Meher Season. 2017/18 (2010 E.C). Statistical Bulletin No 586. Addis Ababa, Ethiopia.

Daneil, M., Gobeze, L., 2012. Response of Pineapple (Anannascomosus (L.)Merrill) Varieties to Organic and Inorganic Fertilizer Rates in Dale and AletaChuko areas of Sidama Zone, in: Eshet, D., Asfaw, Z., Lemma, D., Zemedu, W., Hailemichael, K., Getachew, T., Yehenew, G. (Eds.), Proceedings of the 3rd Biennial Conference of Ethiopian Horticultural Science Society, 4-5 Feb. 2011. Addis Ababa, Ethiopia, pp. 145-166.

Dawit, A., Hailemariam, T., 2008. Marketing of Fruit and Vegetables: Opportunities and Constraints in the Rift Valley of Ethiopia., in: Proceeding of the Ethiopian Horticultural Science Society (EHSS). Vol. I. Proceedings of the First Conference 23-24 March 2006. Addis Ababa, Ethiopia, pp. 26-38.

Debele, D., Fekadu, A.L., 2008. Development of Performance Evaluation of Locally Made Cooling Chambers for Extending the Shelf Life of Mango and Sweet Orange, in: Proceedings of the First Conference of Ethiopian Horticulture Science Society 23-24 March 2006. Addis Ababa, Ethiopia, pp. 51-57.

Edossa, E., Lemma, A. and, Dereje, T., 2008. Review on the Status of some Tropical Crops, in: Proceedings of the First Conference of Ethiopian Horticulture Science Society 23-24 March 2006. Addis Ababa, Ethiopia, pp. 39-44.

Endale, G., Kassa, K., 2008. Assessment of Chilling Conditions and Agronomic Reqirements of Some Temperate Fruit Cultivars at Holetta, in: Proceedings of the First Conference of Ethiopian Horticulture Science Society 23-24 March 2006,. Addis Ababa, Ethiopia, pp. 45-50.

Endeshaw, H., Shimelis, A., Laike, K., 2008. Participatory Demonstration-cum-Evaluation of Natural.ly Ventilated Onion Stores on Small Scale Onion Growing Farmers' Field of the central. Rift Valley., FRG Compiled Research Reports.

Engida, E., Tamru, S., Tsehaye, E., Debowicz, D., Dorosh, P., Robinson, S., 2011. Ethiopia' s Growth and 
Transformation Plan : A Computable General Equilibrium Analysis of Alternative Financing Options. Addis Ababa, Ethiopia.

Etagegnehu, G., Taye, T., and Girefe, S., 2009. Review of Vegetable Crops Weed Research in Ethiopia, in: Abraham, T. (Ed.), Proceeding of Plant Protection Society of Ethiopia. Increasing Crop Production through Improved Plant Protection. PPSE and EIAR, Addis Ababa, Ethiopia, pp. 323-334.

Fantahun, M., Yigzaw, D., 2011. Constraints and opportunities of traditional horticultural crops production systems in the lake tana shore of Amhara region., in: Eshetu Derso, Asfaw Zeleke, Lema Desalegn, Zemedu Worku, Hailemichael K/Mariam, G.T. and Y.G. (Ed.), Proceedings of the Third Biennial Conference of Ethiopian Horticultural Science Society (EHSS), Vol.III, 4-5 February 2011. Addis Ababa, Ethiopia, pp. 305327.

Ferdu, A., Bayeh, M., Emana, G., Temesegen, A., Eyob, T., Messele, G., Brook, and W., 2009a. Review of Entomlogical Research on Root and Tuber Crops in Ethiopia, in: Abraham, T. (Ed.), Proceeding of Plant Protection Society of Ethiopia. Increasing Crop Production through Improved Plant Protection. Addis Ababa, Ethiopia, pp. 1-46.

Ferdu, A., Mohammed, D., Difabachew, B., Bezawork, M., 2009b. Review of Entomological Research on Fruit Crops in Ethiopia, in: Abraham, T. (Ed.), Proceeding of Plant Protection Society of Ethiopia. Increasing Crop Production through Improved Plant Protection. Addis Ababa, Ethiopia, pp. 69-92.

Gashawbeza, A., Bayeh, M., Mulugeta, N., Yeshitila, M., Lidet, S., Ahmed, I., and Tadele, T., 2009. Review of Research on insect and mite pests of vegetable crops in Ethiopia, in: Abraham, T. (Ed.), Proceeding of Plant Protection Society of Ethiopia. Increasing Crop Production through Improved Plant Protection. PPSE and EIAR, Addis Ababa, Ethiopia, pp. 47-67.

Gebremedhin, W., Taye, B., 2013. State of Root, Tuber and Corm Crops Research and Development in Ethiopia Ethiopia, in: Brhane, G., Seme, D., Solomon, B., Taye, B., Solomon, H., Gete, and Z. (Eds.), The State of Agricultural Science and Technology in Ethiopia. Held at International Livestock Research Institute (ILRI) Addis Ababa, Ethiopia. 28-30 November 2011. Ethiopian Academy of Sciences (EAS), Addis Ababa, Ethiopia, pp. 175-199.

Getachew, A.M., 2018. Drought and its impacts in Ethiopia 22, 24-35.

Getachew, T., Asfaw, Z., Dessie, G., 2010. Influence of Plant Density and Nitrogen Fertilization on Yield and Yield Components of Shallot (Al.lium cepa var. ascal.onicum Backer), in: Proceedings of the Second Biannual Conference of Ethiopian Horticultural Science Society (EHSS), 22-23 January 2009. pp. 91-99.

Joosten, F., Boselie, D., Bekele, W. and, Lemma, D., 2011. Exporting Fruit and Vegetables from Ethiopia: Assessment of development potentials and investment options in the export-oriented fruit and vegetable sector. Ethiopian-Netherlands Horticulture Partnership, Study Report. EHDA and EHPEA. Addis Ababa, Ethiopia.

Lemma, D., 2002. Tomatoes: Research Experiences and Production Prospects .Research Report No. 43. Addis Ababa, Ethiopia.

Lemma, D., Seifu, G., Herath, E., 1994a. Seed production studies on vegetables with particular Reference to Onion, in: Hearth, E., Lemma, D. (Eds.), Proceedings of the 2nd National Horticultural Workshop of Ethiopian, 1-3 Dec. 1992. Addis Ababa, Ethiopia, pp. 276-287.

Lemma, D., Shimeles, A., Getachew, T., Selamawit, K., Kebreab, A., 2012. The vegetable seed system: progress, success and challenges in Ethiopia, in: The Defining Moments in Ethiopian Seed System. Addis Ababa, Ethiopia, pp. 461-465.

Lemma, D., Shimels, A., 2003. Research Experiences in Onion Production. Research Report No. 55. Addis Ababa, Ethiopia.

Lemma, D., Yayeh, Z., Getachew, T., Herath, E., 1994b. Varietal Development on Vegetables, in: Hearth, E., Lemma, D. (Eds.), Proceedings of the 2nd National Horticultural Workshop of Ethiopian, 1-3 Dec. 1992. Addis Ababa, Ethiopia, pp. 89-100.

Melkamu, M., Seyoum, T., Woldetsadik, K., 2008. Effects of pre- and post harvest treatments on changes in sugar content of tomato. African J. Biotechnol. 7, 1139-1144.

Mesfin, T., Wondirad, M., Bekele, K., 2009. Review of Research on Diseases of Root and Tuber Crops in Ethiopia, in: Abraham, T. (Ed.), Proceeding of Plant Protection Society of Ethiopia. Increasing Crop Production through Improved Plant Protection. Addis Ababa, Ethiopia, pp. 169-202.

MoA, 2011. The Federal Democratic Republic of Ethiopia Ministry of Agriculture Natural Resource Sector. Small-Scale Irrigation Capacity Building Strategy for Ethiopia. Addis Ababa, Ethiopia.

MoA, (Ministry of Agriculture), 2014. Animal and Plant Health Regulatory Directorate. Crop Variety Register. Issue No. 17. Addis Ababa, Ethiopia.

MoA, (Ministry of Agriculture), ATA, (Agricultural Transformation Agency ), 2011. Household Irrigation Sector Strategy. Realizing the Potential of Household Irrigation in Ethiopia: Vision, Systemic Challenges, and Prioritized Interventions. Working Strategic Document. 
MOA and ATA, 2013. Working strategy document. Realizing the potential of household irrigation in Ethiopia, vision, systemic challenges, and prioritized interventions. Addis Ababa, Ethiopia.

MoALR, (Ministry of Agriculture and Livestock Resource), 2017. Plant Variety Release, Protection and Seed Quality Control Directorate: Crop Variety Register. Issue No. 20. Addis Ababa, Ethiopia.

MoFED, M. of F. and E.D., 2009. Ethiopia: Building on Progress. A Plan for Accelerated and Sustained Development to End Poverty (PASDEP). Addis Ababa, Ethiopia.

Mohammed, Y., Wondirad, M., Eshetu, A., Girma, A., Dereje, T., Tessema, H., Meki, and S., 2009. Review of Research on Fruit Crops Diseases in Ethiopia, in: Abraham, T. (Ed.), Proceeding of Plant Protection Society of Ethiopia. Increasing Crop Production through Improved Plant Protection. Addis Ababa, Ethiopia, pp. 231252.

Mulatu, W., Duguma, A. and, Gezahegn, B., 2012. Solar Drying Of Banana (Musa sp.) Using Solar Cabinet Dryer under Ethiopian Condition., in: Eshet, D., Asfaw, Z., Lemma, D., Zemedu, W., Hailemichael, K., Getachew, T., Yehenew, G. (Eds.), Proceeding of the 3rd Biennial Conference of Ethiopian Horticultural Science Society. 4-5 February 2011. Addis Ababa, Ethiopia, pp. 42-62.

Nicolas, D.C., Mulangu, F., Porto, G., 2012. Food Production and Consumption Trends in Sub-Saharan Africa: Prospects for the Transformation of the Agricultural Sector. UNDP (United Nations Development Program) Working paper, Regional bureau for Africa.

NPC, (National Planning Commission), 2016. Growth and Transformation Plan II (GTP II) . Federal Democratic Republic of Ethiopia. Addis Ababa, Ethiopia.

Sanginga, N., n.d. Root and Tuber Crops ( Cassava, Yam, Potato and Sweet Potato ).

Seid, H., Beshir, H., W/Hawariyat, Y., 2013. Postharvest Loss Assessment of Commercial Horticultural Crops in South Wollo, Ethiopia “Challenges and Opportunities.” Food Sci. Qual. Manag. 17, 34-40.

Seifu, G.-M., 2003. Status of commercial fruit production in Ethiopia. Addis Ababa, Ethiopia.

Selamawit, K., 2013. The State of Science and Technology of Vegetable Crops in Ethiopia, in: Brhane, G., Seme, D., Solomon, B., Taye, B., Solomon, H., Gete, and Z. (Eds.), The State of Agricultural Science and Technology in Ethiopia. Held at International Livestock Research Institute (ILRI) Addis Ababa, Ethiopia. 28-30 November 2011. Ethiopian Academy of Sciences (EAS), Addis Ababa, Ethiopia, pp. 163-179.

Semagn, A., Fentahun, M., 2012. Prospects of cool season vegetables seed production in Ethiopia: Experience from cool highlands of Amhara region, in: Eshet, D., Asfaw, Z., Lemma, D., Zemedu, W., Hailemichael, K., Getachew, T., Yehenew, G. (Eds.), Proceeding of the 3rd Biennial Conference of Ethiopian Horticultural Science Society. 4-5 February 2011. Addis Ababa, Ethiopia, pp. 328-345.

Senayit, Y., Frew, T., and Tiruset, H., 1994. Valuation and Utilization of Some Horticultural Crops, in: Hearth, E., Lemma, D. (Eds.), Proceedings of the 2nd National Horticultural Workshop of Ethiopian, 1-3 Dec. 1992. Addis Ababa, Ethiopia, pp. 301-312.

Tadesse, K.W., 2015. Transactions Costs and Spatial Integration of Vegetable and Fruit Market in Ethiopia. Ethiop. J. Econ. XXIV, 89-130.

Tesfaye, T., Getahun, D., Ermias, S., Shiferaw, M., Temesgene, A., Birhanu, Y., 2013. Current status, Potentials and challenges of Cassava production, processing, marketing and utilization: Evidence from Southern Ethiopia. Greener J. Agric. Sci. 3, 262-270.

Tessema, C., Hearth, E., Sefu, G., 1994. Agronomic Research on Grape, in: Hearth, E., Lemma, D. (Eds.), Proceedings of the 2nd National Horticultural Workshop of Ethiopian, 1-3 Dec. 1992. Addis Ababa, Ethiopia, pp. 147-152.

Woldeamlak, B., 2009. Rainfall variability and crop production in Ethiopia. Case study in the Amhara region.

Wondifraw, T., Dawit, A., Haileab, A., Amsalu, N., Tirfalem, H.W., 2008. Effect of Stand Regulation on Yield and Quality of Pineapple (Annanas comosus (L)mMerr. Var. Smooth Cayenne, in: Proceedings of the First Conference of Ethiopian Horticulture Science Society 23-24 March 2006,. Addis Ababa, Ethiopia, pp. 5863.

Wondirad, M., Eshetu, A., Mohammed, Y., Alemu, L., Yaynu, H., Meki, S., Fekedde, A., 2009. Review of Vegetable Disease Research in Ethiopia, in: Abreham, T. (Ed.), Proceeding of Plant Protection Society of Ethiopia. Increasing Crop Production through Improved Plant Protection. Addis Ababa, Ethiopia, pp. 203230.

World Bank, 2005. The European Horticulture Market: Opportunities for Sub-Saharan African Exporters, World Bank Working Paper No. 63. Washington, D.C., USA. doi:0.1596/978-0-8213-6350-8

Zeberga, S., 2010. Production and Quality Evaluation of Spray Dried Fruit Products. Addis Ababa University. 